
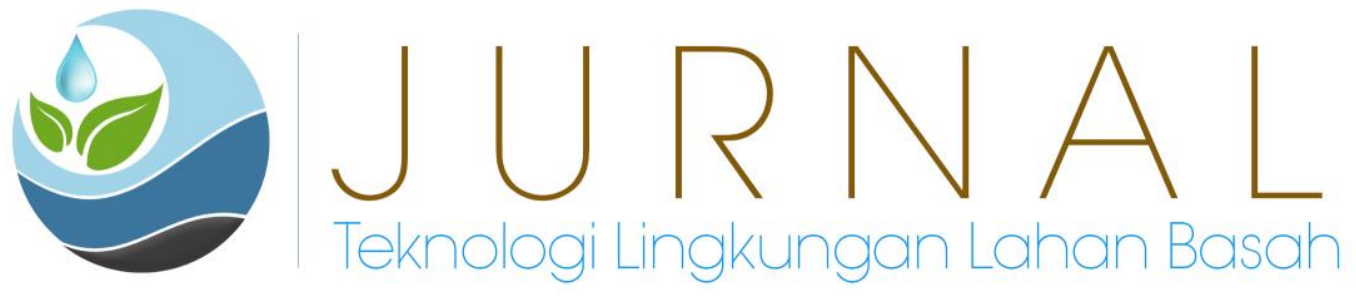

\title{
Efektivitas Limbah Cangkang Kepiting sebagai Biokoagulan dalam Penurunan Kadar Kekeruhan dan Warna Air Baku Sungai Kapuas
}

\author{
Yuda Kurniawan ${ }^{1}$, Rizki Purnaini ${ }^{1}$, dan Govira Christiadora Asbanu' ${ }^{1}$ \\ ${ }^{1}$ Jurusan Teknik Lingkungan Universitas Tanjungpura \\ E-mail : yudaaak@gmail.com
}

\begin{abstract}
Coagulation-flocculation is one of the processes in the Water Treatment Plant which aims to remove suspended particles and colloids. The most widely used coagulant in water treatment plants today is alum. However, the use of alum can have some negative effects on the environment and human health due to its non-biodegradable nature. Crab shells contain substances that can function as deacetylated chitin, namely chitin and chitosan. Chitosan has the ability as a coagulant because it has a lot of nitrogen content in its amine group. The purpose of this study was to determine the effectiveness of crab shell chitosan in reducing turbidity and color of Kapuas River raw water compared to synthetic coagulant, namely alum. The steps of this research include making chitosan and testing the characteristics of crab shell chitosan, determining the $\mathrm{pH}$ and optimum dose using themethod jar test, testing the turbidity and color parameters, and data analysis. The results of the characteristic test of chitosan showed that the yield value of crab shell chitosan was $17,57 \%$, the water content of crab shell chitosan was 3,93\%, and the degree of deacetylation was $94,97 \%$. In the jar test, the optimum dose of chitosan was $300 \mathrm{mg} / \mathrm{l}$ at optimum $\mathrm{pH} 3$ for decreasing turbidity and color parameters. The effectiveness of reducing turbidity by crab shell chitosan was $61,4 \%$ and the color content decreased by $86,35 \%$.
\end{abstract}

Keywords: chitosan, coagulant, coagulation, crab

\begin{abstract}
Abstrak
Koagulasi-flokulasi merupakan salah satu proses di instalasi pengolahan air yang bertujuan menghilangkan partikel tersuspensi dan koloid. Koagulan yang paling banyak digunakan di instalasi pengolahan air saat ini adalah tawas. Namun, penggunaan tawas dapat menimbulkan efek bagi lingkungan dan kesehatan manusia dikarenakan sifatnya yang tidak mudah terbiodegradasi. Cangkang kepiting mengandung zat yang mampu berfungsi sebagai kitin terdeasetilasi yaitu kitin dan kitosan. Kitosan memiliki kemampuan sebagai koagulan karena memiliki banyak kandungan nitrogen pada gugus aminanya. Tujuan dari penelitian ini yaitu mengetahui efektivitas dari kitosan cangkang kepiting dalam menurunkan kadar kekeruhan dan warna air baku Sungai Kapuas dibandingkan dengan koagulan sintetis yaitu tawas. Adapun tahapan penelitian ini meliputi pembuatan kitosan dan uji karakteristik kitosan cangkang kepiting, penentuan pH dan dosis optimum dengan metode jar test, uji parameter kekeruhan dan warna, dan analisis data. Hasil uji karakteristik kitosan menunjukkan nilai rendemen kitosan cangkang kepiting adalah 17,57\%, kadar air kitosan cangkang kepiting yaitu 3,93\%, dan derajat deasetilasi sebesar 94,97\%. Pada uji jar test, didapatkan dosis optimum kitosan adalah $300 \mathrm{mg} / \mathrm{l}$ pada pH optimum 3 untuk penurunan parameter kekeruhan dan warna. Efektivitas penurunan kekeruhan oleh kitosan cangkang kepiting sebesar $61,4 \%$ dan penurunan kadar warna sebesar $86,35 \%$.
\end{abstract}

Kata Kunci: kepiting, kitosan, koagulan, koagulasi

\section{PENDAHULUAN}

Koagulasi-flokulasi merupakan salah satu proses di instalasi pengolahan air yang bertujuan menghilangkan partikel tersuspensi dan koloid. Koagulan yang paling banyak 
digunakan di instalasi pengolahan air saat ini adalah tawas. Namun, penggunaan tawas dapat menimbulkan efek bagi lingkungan dan kesehatan manusia dikarenakan sifatnya yang tidak mudah terbiodegradasi. Hal tersebut mendorong banyak peneliti melakukan penelitian untuk mendapatkan koagulan alami yang mampu menurunkan parameter kekeruhan di dalam air baku.

Cangkang kepiting mengandung zat yang mampu berfungsi sebagai kitin terdeasetilasi yaitu kitin dan kitosan. Kitosan memiliki kemampuan sebagai koagulan karena memiliki banyak kandungan nitrogen pada gugus aminanya. Tujuan dari penelitian ini yaitu mengetahui efektivitas dari kitosan cangkang kepiting dalam menurunkan kadar kekeruhan dan warna air baku Sungai Kapuas dibandingkan dengan koagulan sintetis yaitu tawas.

\section{METODE PENELITIAN}

\section{A. Waktu dan Lokasi Penelitian}

Waktu pelaksanaan penelitian ini kurang lebih selama dua bulan yaitu dari Oktober hingga November 2020. Penelitian ini dilakukan di beberapa lokasi. Pengujian koagulasiflokulasi dengan jar test di Laboratorium Kualitas Air Jurusan Teknik Lingkungan, Fakultas Teknik, Universitas Tanjungpura. Pengambilan sampel air baku berlokasi di dekat unit intake PDAM Tirta Khatulistiwa Jalan Imam Bonjol No. 430, Benua Melayu Laut, Pontianak Selatan, Benua Melayu Laut, Pontianak, Kota Pontianak. Pengambilan limbah cangkang kepiting di restoran seafood Zonna Seafood di Jalan Sultan Abdurrahman, Akcaya, Pontianak Kota, Kota Pontianak. Pengujian parameter kekeruhan dan warna di Laboratorium Kualitas dan Kesehatan Lahan Fakultas Pertanian, Universitas Tanjungpura.

\section{B. Alat dan Bahan}

Adapun alat yang digunakan dalam penelitian ini yaitu jar test (WiseStir), gelas beaker (IWAKI PYREX), gelas ukur (IWAKI PYREX), labu ukur (IWAKI PYREX), magnetic stirrer (IKA C-MAG), oven (BINDER), erlenmeyer (IWAKI PYREX), neraca digital (OHAOUS Pioneer), hot plate (Cimarec+), cawan porselin (IWAKI PYREX), pHmeter (ATC), palu, corong, cawan petri, ayakan 200 mesh, pipet tetes, batang pengaduk, alumunium foil, spatula, dan kertas saring.

Bahan yang digunakan adalah limbah cangkang kepiting, tawas, sampel air baku Sungai Kapuas, larutan $\mathrm{HCl} 1 \mathrm{~N}$, larutan $\mathrm{NaOH} 1 \mathrm{~N}$, larutan $\mathrm{NaOH} 50 \%$, larutan $\mathrm{HCl} 0,1 \mathrm{M}$, larutan $\mathrm{NaOH} 0,1 \mathrm{M}$, indikator metil orange, dan akuades.

\section{Prosedur Penelitian}

\section{Preparasi dan Pembuatan Kitosan Cangkang Kepiting}

Limbah cangkang kepiting dikumpulkan dari restoran Zonna Seafood sebanyak 1 kilogram. Limbah cangkang kepiting dicuci hingga bersih kemudian dijemur sampai kering. Limbah cangkang kepiting dihaluskan menggunakan palu hingga halus kemudian diayak dengan ayakan 200 mesh. Total keseluruhan serbuk cangkang kepiting yang digunakan adalah sebanyak 30 gram untuk pengujian dosis optimum dengan tiga kali pengulangan.

Proses pembuatan kitosan secara kimiawi pada penelitian ini terdiri dari 3 tahap, yaitu demineralisasi, deproteinasi, dan deasetilasi. 


\section{Penentuan pH dan Dosis Optimum}

Penentuan $\mathrm{pH}$ optimum tiap koagulan dilakukan dengan jar test dengan menggunakan dosis optimum yang mengacu pada penelitian sebelumnya, yaitu Amalia (2018). Dosis optimum untuk tawas, serbuk cangkang kepiting, dan kitosan cangkang kepiting secara berurutan adalah $50 \mathrm{mg} / \mathrm{l}, 50 \mathrm{mg} / \mathrm{l}$, dan $150 \mathrm{mg} / \mathrm{l}$. Nilai pH diatur menggunakan larutan $\mathrm{HCl} \mathrm{0,1} \mathrm{M} \mathrm{untuk} \mathrm{mendapatkan} \mathrm{kondisi} \mathrm{asam} \mathrm{dan} \mathrm{larutan}$ $\mathrm{NaOH}$ 0,1 M untuk mendapatkan kondisi basa. Selain itu diuji juga sampel air tanpa penambahan bahan kimia untuk pengkondisian $\mathrm{pH}$ yaitu nilai $\mathrm{pH}$ air sampel Sungai Kapuas. Berikut adalah tabel variasi $\mathrm{pH}$ untuk uji pH optimum.

Tabel 1. Variasi $\mathrm{pH}$ dalam Penentuan $\mathrm{pH}$ Optimum

\begin{tabular}{|c|c|c|c|c|c|c|}
\hline Jenis Koagulan & $\begin{array}{c}\text { Dosis } \\
\text { (mg/l) }\end{array}$ & \multicolumn{3}{|c|}{ pH } \\
\hline Tawas & 50 & $\mathrm{pH}$ asli & 5 & 6 & 7 & 8 \\
\hline Serbuk Cangkang Kepiting & 50 & $\mathrm{pH}$ asli & 3 & 4 & 5 & 6 \\
\hline Kitosan Cangkang Kepiting & 150 & $\mathrm{pH}$ asli & 3 & 4 & 5 & 6 \\
\hline
\end{tabular}

Setelah didapatkan nilai $\mathrm{pH}$ optimum tiap koagulan, selanjutnya dilakukan jar test untuk menguji dosis optimum masing-masing koagulan. Dilakukan uji awal terlebih dahulu yaitu menguji nilai kekeruhan, warna, dan $\mathrm{pH}$ air baku Sungai Kapuas. Variasi dosis tiap koagulan adalah 100, 200, 300, 400 mg/l. Koagulasi dilakukan dengan pengadukan pada kecepatan $100 \mathrm{rpm}$ selama 1 menit setelah penambahan koagulan. Flokulasi dilakukan dengan pengadukan pada kecepatan 60 rpm selama 10 menit, kemudian flok yang terbentuk diendapkan selama 30 menit (AWWA, 1992). Nilai kekeruhan dan warna setelah pengolahan masing-masing koagulan diukur dan dilakukan pengulangan sebanyak tiga kali.

\section{HASIL DAN PEMBAHASAN}

\section{A. Karakteristik Air Sungai Kapuas}

Air Sungai Kapuas adalah salah satu sumber air yang digunakan oleh masyarakat Kalimantan Barat untuk menunjang kehidupan sehari-hari. Namun dewasa ini air Sungai Kapuas sudah tercemar akibat banyaknya aktivitas manusia dari berbagai sektor seperti pemukiman, industri, perdagangan, dan lainnya. Karakteristik air baku Sungai Kapuas sebelum proses koagulasi-flokulasi menggunakan tiga jenis koagulan dalam penelitian ini dapat dilihat pada Tabel 2 di bawah ini.

Tabel 2. Karakteristik Air Baku Sungai Kapuas

\begin{tabular}{|c|c|}
\hline Parameter & Nilai \\
\hline Temperatur & $26^{\circ} \mathrm{C}$ \\
\hline $\mathrm{pH}$ & 6,5 \\
\hline Kekeruhan & $25,4 \mathrm{NTU}$ \\
\hline Warna & $83 \mathrm{mg} / \mathrm{l}$ \\
\hline
\end{tabular}

\section{B. Transformasi Kitosan Cangkang Kepiting}

Tahap demineralisasi bertujuan untuk menghilangkan kandungan mineral dalam cangkang kepiting dengan penambahan larutan asam klorida $(\mathrm{HCl})$. Proses demineralisasi dimulai dengan melarutkan 30 gram serbuk cangkang kepiting dalam $450 \mathrm{ml}$ larutan $\mathrm{HCl}$ $1 \mathrm{~N}$. Hasil residu yang dihasilkan dari proses demineralisasi setelah dioven selama 6 jam pada suhu $80^{\circ} \mathrm{C}$ adalah 10,14 gram. Serbuk hasil proses demineralisasi dapat dilihat pada gambar di bawah ini. 


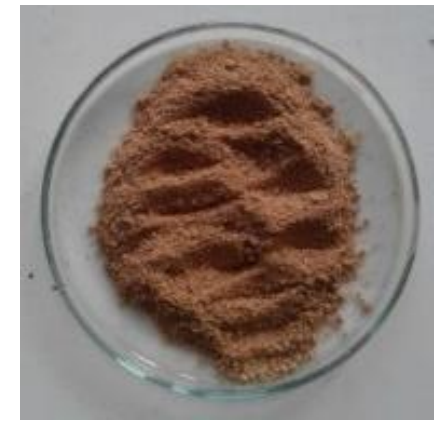

Gambar 1. Hasil Proses Demineralisasi

Tahap deproteinasi bertujuan untuk menghilangkan kandungan protein pada serbuk cangkang kepiting. Proses deproteinasi yaitu dengan melarutkan 10,14 gram serbuk cangkang kepiting dengan 101,4 ml larutan $\mathrm{NaOH} 1 \mathrm{~N}$. Residu yang dihasilkan dari tahap deproteinasi ini yaitu 5,96 gram. Produk hasil tahap deproteinasi seperti dapat dilihat pada gambar berikut.

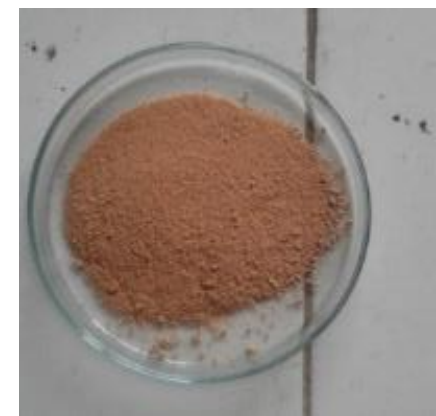

\section{Gambar 2. Hasil Proses Deproteinasi}

Tahap terakhir yaitu tahap deasetilasi yang mengubah kitin menjadi kitosan. Deasetilasi bertujuan untuk menghilangkan gugus asetil dari kitin dengan pemanasan dalam larutan alkali berkonsentrasi kuat. Penghilangan gugus asetil pada tahap deasetilasi ini dengan menambahkan $298 \mathrm{ml}$ larutan $\mathrm{NaOH} 50 \%$ ke dalam 5,96 gram serbuk cangkang. Hasil residu dari tahap ini yaitu sebanyak 5,27 gram dan kitosan yang sudah jadi dapat dilihat pada gambar di bawah ini

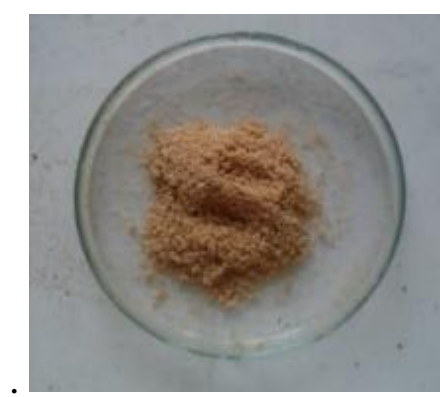

Gambar 3. Kitosan Hasil Proses Deasetilasi

\section{Hasil Karakteristik Kitosan Cangkang Kepiting}

Uji karakteristik kitosan pada penelitian ini terdiri dari tiga yaitu rendemen kitosan, kadar air kitosan, dan derajat deasetilasi kitosan. Rendemen kitosan ditentukan berdasarkan massa kitosan yang dihasilkan terhadap massa bahan baku awal. Massa bahan baku cangkang kepiting awal adalah 30 gram dan setelah melewati tahap pembuatan kitosan secara kimiawi menghasilkan kitosan sebanyak 5,27 gram sehingga hasil perhitungan rendemen kitosan cangkang kepiting yaitu sebesar 17,57\%. Menurut Islama et al. (2011), rendemen kitosan berkisar antara 15,21-18\%. 
Menurut Buckle (1987), kadar air memiliki peranan penting dalam menentukan daya awet bahan karena dapat mempengaruhi sifat fisik, perubahan fisik, perubahan mikrobiologi dan perubahan enzimatis. Perhitungan kadar air kitosan dengan menghitung berat kitosan sebelum dan sesudah dipanaskan dalam oven. Berdasarkan perhitungan, nilai kadar air yang diperoleh adalah 3,93\%. Nilai ini masih memenuhi standar kadar air kitosan yang ditetapkan yaitu 2-10\% (Mozzarelli, 1985).

Penentuan derajat deasetilasi kitosan cangkang kepiting menggunakan metode titrasi dimana kitosan cangkang kepiting dilarutkan dalam larutan $\mathrm{HCl} \mathrm{0,1} \mathrm{M}$ sebanyak $30 \mathrm{ml}$ yang sudah ditetesi indikator metil orange kemudian dititrasi menggunakan larutan $\mathrm{NaOH}$ 0,1 M. Titrasi dihentikan ketika larutan yang awalnya berwarna jingga berubah warna menjadi kemerahan. Volume $\mathrm{NaOH}$ 0,1 M yang didapatkan adalah 24,1 ml sehingga hasil perhitungan derajat deasetilasi kitosan cangkang kepiting ini yaitu sebesar 94,97\%. Nilai ini sudah memenuhi standar mutu kitosan optimum yaitu >70\% (Mozzarelli, 1985).

\section{Penentuan pH Optimum Tiap Jenis Koagulan}

\section{Penentuan pH Optimum Tawas}

Tawas memiliki rentang $\mathrm{pH}$ optimum yaitu 6,0-7,8. Dosis optimum untuk tawas yang digunakan dalam uji $\mathrm{pH}$ optimum yaitu $50 \mathrm{mg} / \mathrm{l}$. Variasi nilai $\mathrm{pH}$ adalah $5,6,7,8$, dan $\mathrm{pH}$ air Sungai Kapuas tanpa perlakuan yaitu 6,6. Hasil jar test untuk uji ph optimum tawas dapat dilihat pada gambar di bawah ini.

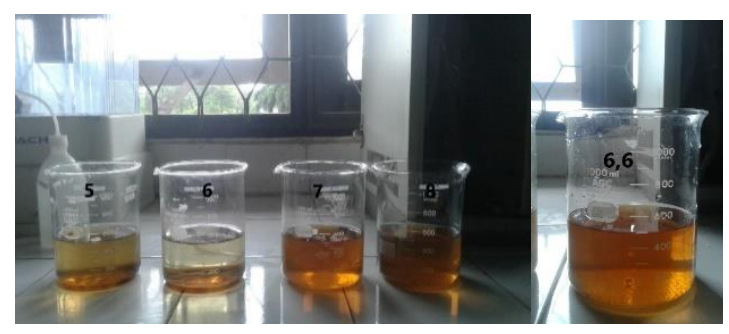

(a)

(b)

Gambar 4. Hasil Jar Test untuk Menentukan pH Optimum Tawas

(a) Variasi pH Perlakuan (b) pH Sampel

Gambar (a) menunjukkan variasi nilai $\mathrm{pH}$ perlakuan berturut-turut dari kiri ke kanan adalah 5, 6, 7, dan 8 sementara pada gambar (b) adalah pH air sampel Sungai Kapuas. Berdasarkan gambar tersebut dapat dilihat endapan yang paling banyak terbentuk adalah pada $\mathrm{pH} 6$ sehingga $\mathrm{pH}$ optimum tawas yang diambil untuk penentuan dosis adalah $\mathrm{pH} 6$.

\section{Penentuan pH Optimum Serbuk Cangkang Kepiting}

Penentuan $\mathrm{pH}$ optimum untuk serbuk cangkang kepiting dilakukan dengan variasi perlakuan $\mathrm{pH} 3,4,5$, 6, dan $\mathrm{pH}$ air sampel Sungai Kapuas yaitu 6,6. Dosis serbuk cangkang kepiting yang digunakan adalah $50 \mathrm{mg} / \mathrm{l}$. Setelah masing-masing air sampel diberi perlakuan hingga mencapai $\mathrm{pH}$ yang diinginkan, selanjutnya dilakukan jar test. 


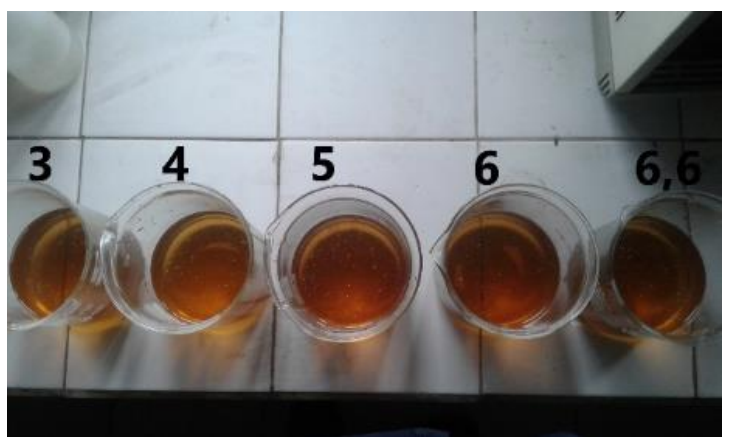

Gambar 5. Hasil Jar Test untuk Menentukan pH Optimum Serbuk Cangkang Kepiting

Berdasarkan seberapa banyak endapan yang terbentuk setelah proses koagulasiflokulasi dengan metode jar test tersebut, sampel yang membentuk endapan paling banyak adalah pada $\mathrm{pH} 3$ sehingga dipilih sebagai $\mathrm{pH}$ optimum yang digunakan untuk penentuan dosis optimum.

\section{Penentuan pH Optimum Kitosan Cangkang Kepiting}

Pengujian $\mathrm{pH}$ optimum untuk kitosan cangkang kepiting memiliki variasi $\mathrm{pH}$ yang sama dengan pengujian $\mathrm{pH}$ optimum serbuk cangkang kepiting yaitu 3, 4, 5, 6, dan pH air sampel tanpa perlakuan 6,6. Dosis yang digunakan adalah $150 \mathrm{mg} / \mathrm{l}$.

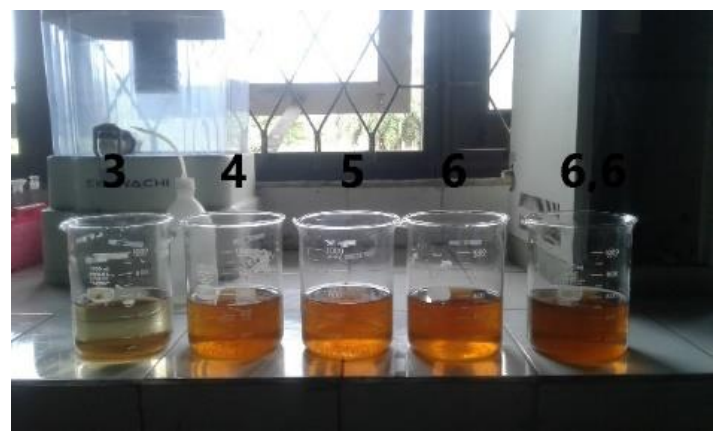

Gambar 6. Hasil Jar Test untuk Menentukan pH Optimum Kitosan Cangkang Kepiting

Variasi $\mathrm{pH}$ berturut-turut dari kiri ke kanan adalah 3, 4, 5, 6, dan $\mathrm{pH}$ tanpa perlakuan. Terlihat dari gambar di atas air sampel dengan perlakuan $\mathrm{pH} 3$ memiliki kondisi paling jernih dibandingkan air sampel lainnya dan membentuk paling banyak endapan sehingga diambil nilai $\mathrm{pH}$ optimum untuk kitosan cangkang kepiting yaitu pada $\mathrm{pH} 3$.

\section{Penentuan Dosis Optimum Tiap Jenis Koagulan}

Hasil jar test uji dosis optimum untuk ketiga koagulan yang digunakan dapat dilihat pada gambar di bawah ini.

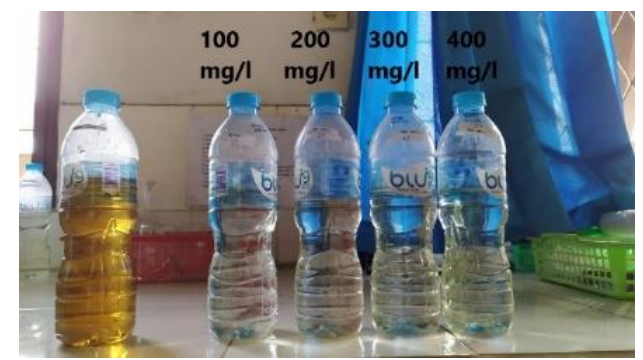

Gambar 7. Hasil Jar Test dengan Variasi Dosis Koagulan Tawas 


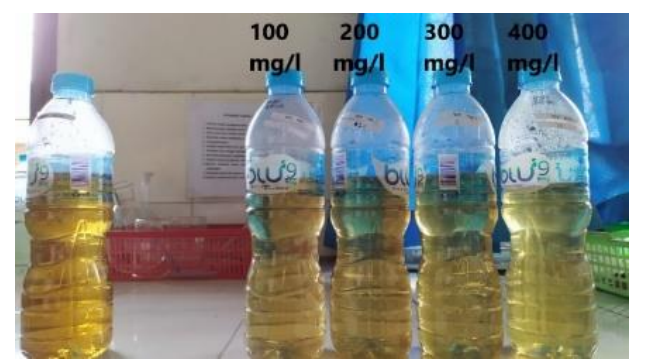

Gambar 8. Hasil Jar Test dengan Variasi Dosis Serbuk Cangkang Kepiting

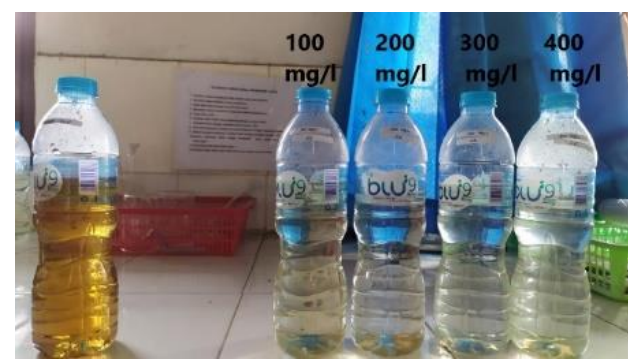

Gambar 9. Hasil Jar Test dengan Variasi Dosis Kitosan Cangkang Kepiting

Hasil analisis laboratorium untuk kekeruhan air baku Sungai Kapuas sebelum dan sesudah pengujian dapat dilihat pada Tabel 4.2 dan kadar warna air baku Sungai Kapuas sebelum dan sesudah perlakuan pada Tabel 4.3.

Tabel 3. Hasil Uji Parameter Kekeruhan Air Sungai Kapuas

\begin{tabular}{|c|c|c|c|c|c|c|c|}
\hline \multirow{4}{*}{ Koagulan } & \multirow{4}{*}{$\begin{array}{l}\text { Dosis } \\
(\mathrm{mg} / \mathrm{l})\end{array}$} & \multirow{4}{*}{$\begin{array}{c}\mathrm{pH} \\
\text { Optimum }\end{array}$} & \multirow{4}{*}{$\begin{array}{c}\text { Kekeruhan } \\
\text { Awal } \\
\text { (NTU) }\end{array}$} & \multirow{3}{*}{\multicolumn{3}{|c|}{$\begin{array}{c}\text { Kekeruhan Akhir (NTU) } \\
\text { Ulangan }\end{array}$}} & \multirow{4}{*}{$\begin{array}{c}\text { Rata- } \\
\text { rata }\end{array}$} \\
\hline & & & & & & & \\
\hline & & & & & & & \\
\hline & & & & 1 & 2 & 3 & \\
\hline \multirow{4}{*}{ Tawas } & 100 & \multirow{4}{*}{6} & \multirow{12}{*}{25,4} & 9,60 & 14,00 & 7,05 & 10,22 \\
\hline & 200 & & & 12,09 & 12,05 & 12,04 & 12,06 \\
\hline & 300 & & & 14,30 & 13,40 & 14,20 & 13,97 \\
\hline & 400 & & & 11,50 & 14,50 & 15,70 & 13,90 \\
\hline \multirow{4}{*}{$\begin{array}{c}\text { Serbuk } \\
\text { cangkang } \\
\text { kepiting }\end{array}$} & 100 & \multirow{4}{*}{3} & & 20,40 & 30,20 & 43,50 & 31,37 \\
\hline & 200 & & & 25,40 & 26,11 & 33,50 & 28,34 \\
\hline & 300 & & & 25,30 & 30,40 & 35,40 & 30,37 \\
\hline & 400 & & & 23,40 & 23,50 & 25,40 & 24,10 \\
\hline \multirow{4}{*}{$\begin{array}{c}\text { Kitosan } \\
\text { cangkang } \\
\text { kepiting }\end{array}$} & 100 & \multirow{4}{*}{3} & & 14,50 & 11,20 & 13,07 & 12,92 \\
\hline & 200 & & & 7,05 & 12,40 & 12,50 & 10,65 \\
\hline & 300 & & & 4,92 & 13,40 & 11,09 & 9,80 \\
\hline & 400 & & & 14,30 & 14,40 & 15,09 & 14,60 \\
\hline
\end{tabular}


Tabel 4. Hasil Uji Parameter Warna Air Sungai Kapuas

\begin{tabular}{|c|c|c|c|c|c|c|c|}
\hline \multirow{3}{*}{ Koagulan } & \multirow{3}{*}{$\begin{array}{l}\text { Dosis } \\
(\mathrm{mg} / \mathrm{l})\end{array}$} & \multirow{3}{*}{$\begin{array}{c}\mathrm{pH} \\
\text { Optimum }\end{array}$} & \multirow{3}{*}{$\begin{array}{c}\text { Warna } \\
\text { Awal } \\
(\mathrm{mg} / \mathrm{l})\end{array}$} & Warı & $\mathrm{Akh}$ & $\mathrm{ng} / \mathrm{l})$ & \multirow{3}{*}{$\begin{array}{l}\text { Rata- } \\
\text { rata }\end{array}$} \\
\hline & & & & \multicolumn{3}{|c|}{ Ulangan } & \\
\hline & & & & 1 & 2 & 3 & \\
\hline \multirow{4}{*}{ Tawas } & 100 & \multirow{4}{*}{6} & \multirow{12}{*}{83} & 12 & 16 & 12 & 13,33 \\
\hline & 200 & & & 17 & 16 & 14 & 15,67 \\
\hline & 300 & & & 19 & 16 & 16 & 17 \\
\hline & 400 & & & 14 & 16 & 19 & 16,33 \\
\hline \multirow{4}{*}{$\begin{array}{c}\text { Serbuk } \\
\text { cangkang } \\
\text { kepiting }\end{array}$} & 100 & \multirow{4}{*}{3} & & 63 & 62 & 63 & 62,67 \\
\hline & 200 & & & 55 & 58 & 60 & 57,67 \\
\hline & 300 & & & 55 & 60 & 60 & 58,33 \\
\hline & 400 & & & 55 & 54 & 56 & 55 \\
\hline \multirow{4}{*}{$\begin{array}{c}\text { Kitosan } \\
\text { cangkang } \\
\text { kepiting }\end{array}$} & 100 & \multirow{4}{*}{3} & & 11 & 15 & 15 & 13,67 \\
\hline & 200 & & & 8 & 15 & 14 & 12,33 \\
\hline & 300 & & & 6 & 14 & 14 & 11,33 \\
\hline & 400 & & & 25 & 15 & 16 & 18,67 \\
\hline
\end{tabular}

Penurunan kadar kekeruhan dan warna air Sungai Kapuas menggunakan tiga jenis koagulan dapat dilihat pada Gambar 10.
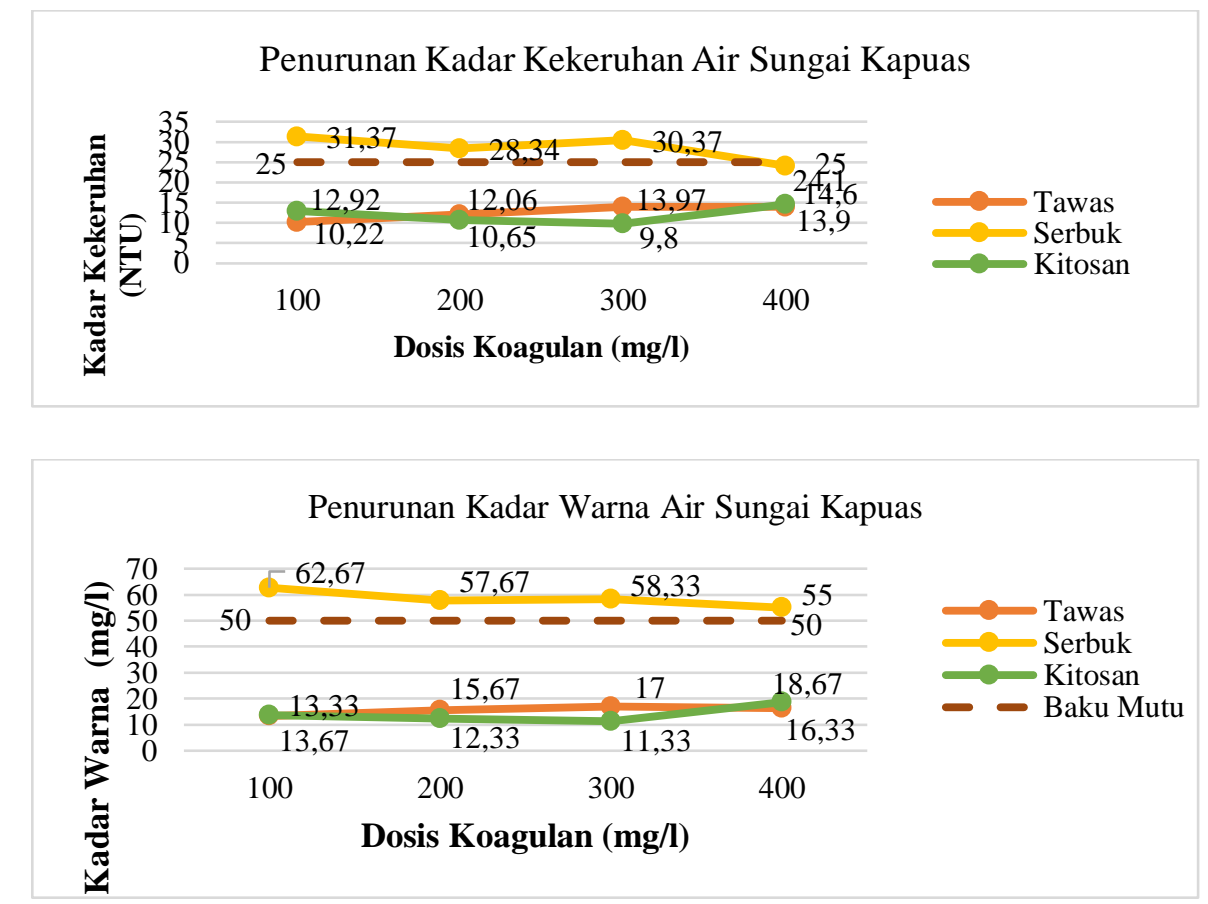

Gambar 10. Grafik Penurunan Kadar Kekeruhan dan Warna Air Sungai Kapuas

\section{Tingkat Efektivitas Penurunan Kadar Kekeruhan dan Warna Air Baku Sungai Kapuas}

Setelah data kadar kekeruhan dan warna didapatkan, kemudian dihitung persentase efektivitas penurunan setiap parameter untuk melihat seberapa besar setiap koagulan menyisihkan kadar kekeruhan dan warna di air baku Sungai Kapuas. Efektivitas 
penurunan kadar kekeruhan dari ketiga koagulan dalam penelitian ini dapat dilihat pada Tabel 5 berikut ini.

Tabel 5. Efektivitas Penurunan Kadar Kekeruhan Air Sungai

Kapuas

\begin{tabular}{|c|c|c|c|c|}
\hline Koagulan & $\begin{array}{l}\text { Dosis } \\
(\mathrm{mg} / \mathrm{l})\end{array}$ & $\begin{array}{c}\text { Kekeruhan } \\
\text { Awal } \\
\text { (NTU) }\end{array}$ & $\begin{array}{l}\text { Kekeruhan } \\
\text { Akhir Rata- } \\
\text { rata (NTU) }\end{array}$ & $\begin{array}{c}\text { Efektivitas } \\
(\%)\end{array}$ \\
\hline \multirow{4}{*}{ Tawas } & 100 & \multirow{12}{*}{25,4} & 10,22 & 59,78 \\
\hline & 200 & & 12,06 & 52,52 \\
\hline & 300 & & 13,97 & 45,01 \\
\hline & 400 & & 13,90 & 45,28 \\
\hline \multirow{4}{*}{$\begin{array}{c}\text { Serbuk } \\
\text { cangkang } \\
\text { kepiting }\end{array}$} & 100 & & 31,37 & - \\
\hline & 200 & & 28,34 & - \\
\hline & 300 & & 30,37 & - \\
\hline & 400 & & 24,10 & 5,12 \\
\hline \multirow{4}{*}{$\begin{array}{l}\text { Kitosan } \\
\text { cangkang } \\
\text { kepiting }\end{array}$} & 100 & & 12,92 & 49,12 \\
\hline & 200 & & 10,65 & 58,07 \\
\hline & 300 & & 9,80 & 61,40 \\
\hline & 400 & & 14,60 & 42,53 \\
\hline
\end{tabular}

Berdasarkan tabel di atas, maka dapat dilihat bahwa kekeruhan awal sebesar 25,4 NTU dapat diturunkan dengan persentase efektivitas penurunan yang berbeda-beda pada tiap variasi dosis koagulan. Efektivitas penurunan kekeruhan tertinggi dari ketiga koagulan tersebut yaitu oleh koagulan kitosan cangkang kepiting yang dapat menyisihkan kekeruhan sebesar 61,4\% pada dosis $300 \mathrm{mg} / \mathrm{l}$.

Selanjutnya, efektivitas penurunan kadar warna air Sungai Kapuas menggunakan tiga jenis koagulan yang berbeda dapat dilihat pada Tabel 6 di bawah ini.

Tabel 6. Efektivitas Penurunan Kadar Warna Air Sungai Kapuas

\begin{tabular}{|c|c|c|c|c|}
\hline Koagulan & $\begin{array}{l}\text { Dosis } \\
(\mathrm{mg} / \mathrm{l})\end{array}$ & $\begin{array}{l}\text { Warna } \\
\text { Awal } \\
(\mathrm{mg} / \mathrm{l})\end{array}$ & $\begin{array}{c}\text { Warna } \\
\text { Akhir Rata- } \\
\text { rata }(\mathrm{mg} / \mathrm{l})\end{array}$ & $\begin{array}{c}\text { Efektivitas } \\
(\%)\end{array}$ \\
\hline \multirow{4}{*}{ Tawas } & 100 & \multirow{12}{*}{83} & 13,33 & 83,94 \\
\hline & 200 & & 15,67 & 81,12 \\
\hline & 300 & & 17 & 79,52 \\
\hline & 400 & & 16,33 & 80,32 \\
\hline \multirow{4}{*}{$\begin{array}{l}\text { Serbuk } \\
\text { cangkang } \\
\text { kepiting }\end{array}$} & 100 & & 62,67 & 24,50 \\
\hline & 200 & & 57,67 & 30,52 \\
\hline & 300 & & 58,33 & 29,72 \\
\hline & 400 & & 55 & 33,73 \\
\hline \multirow{4}{*}{$\begin{array}{l}\text { Kitosan } \\
\text { cangkang } \\
\text { kepiting }\end{array}$} & 100 & & 13,67 & 83,53 \\
\hline & 200 & & 12,33 & 85,14 \\
\hline & 300 & & 11,33 & 86,35 \\
\hline & 400 & & 18,67 & 77,51 \\
\hline
\end{tabular}


Persentase penurunan parameter warna untuk setiap dosis masing-masing koagulan juga bervariasi. Persentase penurunan parameter warna tertinggi dari ketiga koagulan tersebut adalah kitosan cangkang kepiting dengan efektivitas penurunan warna sebesar $86,35 \%$ pada perlakuan dosis $300 \mathrm{mg} / \mathrm{l}$.

\section{PENUTUP}

\section{KESIMPULAN}

Kesimpulan yang dapat diambil dari penelitian ini yaitu sebagai berikut:

1. Dosis optimum kitosan cangkang kepiting dalam menurunkan kekeruhan yaitu 300 $\mathrm{mg} / \mathrm{l}$ pada $\mathrm{pH} 3$ dan dosis optimum dalam menurunkan warna yaitu $300 \mathrm{mg} / \mathrm{l}$ pada $\mathrm{pH}$ 3.

2. Kitosan cangkang kepiting memiliki kemampuan sebagai biokoagulan dimana hal ini ditunjukkan dengan efektivitas penurunan kadar kekeruhan sebesar $61,4 \%$ dan penurunan kadar warna sebesar $86,35 \%$. Persentase penurunan kekeruhan dan warna kitosan cangkang kepiting yang lebih tinggi dibandingkan koagulan tawas menunjukkan bahwa kitosan cangkang kepiting dapat berperan mendampingi tawas sebagai koagulan utama dalam pemanfaatannya di PDAM.

\section{SARAN}

Sebaiknya pada penelitian selanjutnya pengujian karakteristik kitosan cangkang kepiting seperti uji derajat deasetilasi dicari metode yang lebih baik agar mengurangi tingkat error dalam penelitian.

\section{UCAPAN TERIMAKASIH}

Puji dan syukur saya panjatkan ke hadirat Allah SWT yang karena berkat rahmat dan hidayah-Nya sehingga saya dapat menyelesaikan skripsi dengan judul "Efektivitas Limbah Cangkang Kepiting Sebagai Biokoagulan dalam Penurunan Kadar Kekeruhan dan Warna Air Baku Sungai Kapuas". Pada kesempatan ini saya ingin mengucapkan terima kasih kepada Ibu Dr. Rizki Purnaini, S.T., M.T. selaku Dosen Pembimbing Utama dan Ibu Govira Christiadora Asbanu, S.Pd.Si, M.Sc. selaku Dosen Pembimbing Kedua atas bimbingan, masukan dan saran, serta motivasi yang diberikan.

\section{DAFTAR PUSTAKA}

Amalia, A. N. 2018. Pemanfaatan Cangkang Rajungan Sebagai Koagulan untuk Penjernih Air. Tugas Akhir. Yogyakarta: Universitas Islam Indonesia.

AWWA. 1992. Operational Control of Coagulation and Filtration Processes. Colorado: American Water Work Association.

Buckle, K. A. 1987. Ilmu Pangan. Jakarta: Universitas Indonesia Press.

Islama, M.; Masum, S.; Rahmana, M.M.; Mollab, A.I.; Shaikh, A.A., dan Roya, S.K. 2011. Preparation of Chitosan from Shrimp Shell and Investigation of Its Properties. Journal of Basic and Applied Sciences, Vol. 11 (1), pp. 1-10.

Laila, A., dan Hendri, J. 2008. Studi Pemanfaatan Polimer Kitin Sebagai Media Pendukung Amobilisasi Enzim $\alpha$-Amilase. Lampung: Jurusan Kimia Fakultas MIPA.

Muzzarelli, R. A. A. 1985. Chitin in The Polysaccharides. Vol. 3, pp 147. Orlando, San Diego: Academic Press Inc.

Saleh, M. T. A.; Agustin, P. S., dan E. S., Heruwati. 1999. Pembuatan Kitosan dari Kulit Udang Windu (Penaeus monodon) dan Uji Koagulasi Proteinnya. Jurnal Penelitian Perikanan Indonesia. Vol. 5 (3). Hlm. 72-77. 